\title{
Strategy and performance of South African listed family companies
}

\author{
Rob Mackintosh \\ Department of Business Administration, Rhodes University, Grahamstown
}

An impressive body of theory on organizational development, performance, strategy and structure has developed over the last two decades. Much of what we know stems from direct observation (usually in the form of case-studies), first-hand experlence, and common sense. Yet surprisingly little attempt has been made to test the theories and provide an empirical base with which to confirm or reject the theories. This study suggests that the traditional theories of organizational development are vindicated - that firms develop from entrepreneurial, family companies in the first stage to professional management in later stages. Furthermore, an analysis of share-price movements suggests that single business family companies on the Johannesburg Stock Exchange do not perform as well as those which adopt more diversified strategies. This study builds on the small base of previous research, and hopefully makes a contribution to our knowledge both in the academic/teaching sphere of business policy, and in the area of organizational change.

S. Afr. J. Bus. Mgmt 1980, 10: 5-8

'n Indrukwekkende versameling van teorie oor organisasieontwikkeling, en die prestasle, strategle en struktuur van ondernemings is oor die afgelope twee dekades ontwikkel. Ons kennis het ontstaan uit direkte waarneming (gewoonlik in die vorm van gevallestudies), ele ervaring, en gesonde verstand. Tog is min pogings aangewend om die teoriee te toets en 'n empiriese basis te skep waarvolgens die teoriee bevestig of verwerp kan word. Hierdie studie stel voor dat die tradisionele teories van organisasie-ontwikkeling geregverdig is dat firmas van entrepreneuriêle familie-ondernemings in die eerste stadium, tot professionele bestuur in latere stadia ontwikkel. Verder dui 'n ontleding van aandeleprys-bewegings aan dat enkelbedryf familiemaatskappye op die Johannesburgse Aandelebeurs nie so goed vertoon as dié wat meer gediversifiseerde strategiee aanvaar het nie. Hierdie studie bou voort op die klein basis van vorige navorsing, en maak hopelik ' $n$ bydrae tot kennis sowel in die akademiese/onderrigsfeer van bestuursbeleid, as op die gebied van organisasieverandering.

S.-Afr. Tydskr. Bedryfsl. 1980, 11: 5-8

R.G.J. Mackintosh

Department of Business Administration, Rhodes University, P.O. Box 94, Grahamstown 6140, South Africa

New address:

Senior Lecturer, Graduate School of Business, University of Cape Town,

Rondebosch 7700, South Africa
The growth and development of organizations is a subject which has attracted much attention over the last 20 years or so. In this paper I propose to examine how well listed family companies in South Africa have performed in each stage of organizational development.

\section{Organizational development theory}

A number of authors have proposed that organizational development takes place through a definite sequence of stages. One of these authors, Scott' identifies three distinct stages, which can be described briefly as follows: Stage $1-$ is the Pioneer or Entrepreneurial phase, in which the founder/owner brings the business into existence through his own drive and initiative. The business has little or no formal organizational structure, sells a single product or product-line, has no systematic rewardstructure for employees, and control is exercised by the owner-manager himself. Critical strategic choices which face the business relate strongly to the needs of the founder. His own need to control the business destiny, to feel that he is indispensible, may lead to a crisis of leadership which, if not successfully resolved, could spell the demise of the business.

Stage 2 - signifies a transition from family-based firms to professionally managed organizations, with functional specialization, rules and procedures, formal control and reward structure, with well-defined communication channels. The advent of professional management makes it possible for the business to greatly expand its operations, geographically and in terms of new product introductions.

Here too a crisis stage is reached, as increasingly initiative is smothered, decision-making becomes bureaucratic and cumbersome, and the organization is generally sluggish to react effectively to a changing environment.

Stage 3 - firms generally attempt to resolve the Stage 2 crisis through teamwork, and improved integrative mechanisms, such as task-teams and matrix organizational structures.

Wrigley $^{2}$ has identified four major product-market strategies which are adopted by companies as they progress through the stages of organizational development: Single Business, Dominant Business, Related Business, and Unrelated Business. These may be seen as corresponding roughly to the three stages suggested by Scott, with Related and Unrelated occupying Stage 3. (Table 1). 
Table 1 Summary of strategic categories*

\begin{tabular}{|c|c|c|c|c|}
\hline & Single Businesses & Dominant Business & Related Business & Unrelated Business \\
\hline $\begin{array}{l}\text { Specialization ratio } \\
\text { The proportion of a firm's } \\
\text { revenues attributable to its } \\
\text { largest discrete product- } \\
\text { market activity }\end{array}$ & $\begin{array}{l}\text { Largely in a single } \\
\text { business. Has a ratio } \\
\text { of } 0,95 \text { or more }\end{array}$ & $\begin{array}{l}\text { Firms that have } \\
\text { diversified to a small } \\
\text { extent. Has a ratio of } \\
\text { between } 0,7 \text { and } 0,95\end{array}$ & $\begin{array}{l}\text { Diversified firm's } \\
\text { which have a ratio of } \\
\text { less than } 0,7\end{array}$ & $\begin{array}{l}\text { Ratio considerably } \\
\text { below } 0,7\end{array}$ \\
\hline $\begin{array}{l}\text { Related ratio } \\
\text { The proportion of the firm's } \\
\text { revenues derived from the } \\
\text { largest group of business ac- } \\
\text { tivities that are related in } \\
\text { some way to one another }\end{array}$ & & & $\begin{array}{l}\text { Has a related ratio } \\
\text { of } 0,7\end{array}$ & $\begin{array}{l}\text { Has a related ratio } \\
\text { of } 0,7 \text { or less }\end{array}$ \\
\hline $\begin{array}{l}\text { Vertical ratio } \\
\text { The proportion of the firm's } \\
\text { revenues attributable to all } \\
\text { of the by-products, interme- } \\
\text { diate products and final pro- } \\
\text { ducts of a vertically inte- } \\
\text { grated sequence of manufac- } \\
\text { turing operations }\end{array}$ & $\begin{array}{l}\text { Has a ratio of } 0,7 \text { or } \\
\text { more }\end{array}$ & $\begin{array}{l}\text { Has a ratio of } 0,7 \text { or } \\
\text { more }\end{array}$ & & \\
\hline
\end{tabular}

*Andrews, G.S. Strategy and financial performance of South African industrial companies, 1970-1976. Unpubl. Ph.D. Thesis, Graduate School of Business, University of Cape Town, pp.312-316.

\section{Product-market strategy - the evidence}

The product-market strategy approach is based on the concept of 'core skills'. Each company possesses a group of core skills which it uses in its market(s). Wrigley proposed that diversification strategies which build upon these core skills are more likely to succeed than diversification strategies which are unrelated to the organization's core skills.

In a recent study using Wrigley's framework, G.S. Andrews ${ }^{3}$ examined the strategy and financial performance of 277 South African industrial companies between 1970 - 1976. Andrews adopted a refinement on Wrigley's framework, developed by Rumelt, ${ }^{4}$ which further divided the four major product-market strategies into nine subcategories (Table 2).

Andrews found that the Single Business and Dominant Business firms performed worse than those which

Table 2 Strategic product-market categories of 277 South African listed companies for the period $1970-1976$ inclusive*

\begin{tabular}{lcccc}
\hline & \multicolumn{3}{c}{$\%$ of companies in each subcategory } \\
\cline { 2 - 5 } Subcategories & $\begin{array}{c}\text { Single } \\
\text { Business }\end{array}$ & $\begin{array}{c}\text { Dominant } \\
\text { Business }\end{array}$ & $\begin{array}{c}\text { Related } \\
\text { Business }\end{array}$ & $\begin{array}{c}\text { Unrelated } \\
\text { Business }\end{array}$ \\
\hline Vertical & & D-V 7,9 & & \\
Constrained & & D-C 18,9 & R-C 6,8 & \\
Linked & & D-L 7,9 & R-L 5,8 & \\
$\begin{array}{l}\text { Unrelated } \\
\text { Single }\end{array}$ & D-U 5,0 & & \\
Passive & & & & U-P 5,8 \\
Conglomerate & & & & C 6,8 \\
Total (\%) & 35,3 & 39,2 & 12,9 & 12,6 \\
\hline
\end{tabular}

*Andrews, G.S. Strategy and financial performance of South African industrial companies. Unpubl. Ph.D. Thesis, Graduate School of Business, University of Cape Town, 1979, p.350,

Table 6-2. adopted more diversified strategies, especially Related Business and Conglomerate strategies. This tends to confirm that, in general, the more diversified industrial companies are superior performers.

\section{Research hypothesis}

On the basis of Scott's three stage model of organizational development, the first hypothesis is that

$H 1$ : : family ownership and management of listed companies will be found predominantly in the first stage of development (that is the Single Business strategy).

On the basis of Andrews's findings relating to the performance of Single Business and Dominant Business strategies, the second hypothesis is that

H 2 : : listed family companies in the Single Business and Dominant Business categories perform worse than those in the Related and Unrelated Business categories.

\section{Research methodology}

To test the first hypothesis, a study by Ian Morgan ${ }^{5}$ provided the two criteria used to identify and select family companies listed on the Johannesburg Stock Exchange.

A listed company is considered to be a family company when:

o at least two directors are related; and

- their shareholding is sufficiently large to achieve effective control in the hands of the board of directors.

The test for family control therefore includes both a controlling interest and the presence of active family members of the board.

Two additional companies - the Rembrandt Group and the Anglo American Corporation - were included in the population because of their family ownership presence on the Board, and large scale industrial holdings. 
Morgan's list was matched against Andrews' categorization of listed companies, to determine how many family companies were in each product-market category (Table 3). Of 105 family companies identified, 51 fell into Andrews' classification, in that they had not changed their product-market strategy in the 1970-1976 period.

For the second hypothesis, share-price movements were obtained from the Investor's Guide for the 51 family companies, and compared against the pricemovements of the RDM 100 for each company.

Share price movements are regarded as the most objective market measure of company performance. Companies whose performance was superior to the market as a whole were expected to show proportionately greater increases in share price than the market as a whole, or a smaller drop in share price in a bear market.

The RDM 100 is adopted as an adequate measure of average market share-price movements. Annual share price changes were compared with changes in the RDM 100 and year-end figures were recorded as better (B), worse (W), or the same (S) as the movement of the RDM 100. This made it possible to compare movements between the different categories of product-market strategy (Single Business, Dominant, Related and Unrelated Business).

A five-year period was considered sufficient to test the general movements in share-prices, and the period $1973-1977$, which substantially overlaps the period of Andrews' study, was chosen.

\section{The research findings}

The number of family companies has declined since 1971 from 150 to slightly more than 100. This one-third decrease indicates that the families are experiencing considerable difficulty in making the adaptations necessary to survive in a changing environment. Some of the family companies have not survived, while others have been taken over by holding companies which do have the expertise to move the business into its next logical stage of development.

The 100-odd survivors since 1971 are evenly divided between those which have not changed their productmarket category in the period 1970-1976, and those which have developed new market postures. The high proportion of family companies in transition is in a way reassuring. It indicates that the willingness to experiment with new products and markets in some measure, is strong. Of the 50-odd companies which have remained in their categories since 1970, fully half are still in the single business category. Locked into 'the business we know and can manage', and without much prospect of rapid growth in existing markets, the Single Business family companies are poor performers, and seem unlikely to attract much investor confidence or capital for expansion.

\section{Single business and core skills}

Of the sample of 51 family-held companies, $78 \%$ are in the Single and Dominant Business categories (Table 3). Andrews' study showed that $75 \%$ of industrial companies were in these two categories. Far more (in percentage terms), however, of family businesses are in the Single Business category - $51 \%$ compared to $35 \%$ for all
Table 3 Distribution of family-held companies which were listed on the Johannesburg Stock Exchange for the period 1970-1976, and which retained the same strategic classification in terms of products-markets throughout this period

No. of companies (and \%) in each category

\begin{tabular}{lcccc}
\cline { 2 - 5 } Subcategories & $\begin{array}{c}\text { Single } \\
\text { Business }\end{array}$ & $\begin{array}{c}\text { Dominant } \\
\text { Business }\end{array}$ & $\begin{array}{c}\text { Related } \\
\text { Business }\end{array}$ & $\begin{array}{c}\text { Unrelated } \\
\text { Business }\end{array}$ \\
\hline Vertical & & $4(8 \%)$ & & \\
Constrained & $1(2 \%)$ & $6(12 \%)$ & \\
Linked & & $5(10 \%)$ & & \\
Unrelated & & $4(8 \%)$ & & $4(8 \%)$ \\
Single & $26(50 \%)$ & & & $1(2 \%)$ \\
Passive & & & & $5(10 \%)$ \\
Conglomerate & & & $6(12 \%)$ & \\
Total & $26(50 \%)$ & $14(28 \%)$ & 6
\end{tabular}

industrial companies used in Andrews' research. This indicates that family businesses are more likely to be in a single business than professionally managed companies. This supports the view that family concerns generally lack the management skills to attempt almost any significant diversification away from the core skills of the business.

\section{Performance of Single businesses}

In comparison with the RDM 100 index, Single Business family companies (in the period 1973-1977) outperformed the market only $34 \%$ of the time, while they performed worse than the market average $54 \%$ of the time (Table 4). This tends to corroborate Andrews' findings that the Single Business group as a whole had the lowest return on invested capital (ROIC) $-14,31 \%$ (Table 5).

\section{Performance of Dominant businesses}

The Dominant Business category accounts for $27 \%$ of family businesses, and is the second largest category. There are four subcategories: Dominant-Vertical, Dominant-Constrained, Dominant-Linked, and Dominant-Unrelated. The worst strategy appears to be

Table 4 The share price performance of 51 family. held companies on the Johannesburg Stock Exchange against the share-price performance of the RDM 100

\begin{tabular}{|c|c|c|c|c|}
\hline & $\begin{array}{c}\text { Single } \\
\text { Business }\end{array}$ & $\begin{array}{c}\text { Dominant } \\
\text { Business }\end{array}$ & $\begin{array}{l}\text { Related } \\
\text { Business }\end{array}$ & $\begin{array}{l}\text { Unrelated } \\
\text { Business }\end{array}$ \\
\hline Subcategories & W B S & W B S & W B S & W B S \\
\hline Vertical & & 572914 & & \\
\hline Constrained & & 404020 & 38548 & \\
\hline Linked & & 393922 & --- & \\
\hline Unrelated & & 315019 & & \\
\hline
\end{tabular}

Passive

602713

Conglomerate

206020

The figures in this table indicate the percentage of occasions in which family companies performed better (B), worse than (W), or the same as (S) the RDM 100 over the period 1973-1977. 
Table 5 Return on invested capital rankings of the nine major subcategories of strategic productmarket relationships*

\begin{tabular}{llc}
\hline & \multicolumn{2}{l}{ Return on invested capital } \\
\cline { 2 - 3 } Strategic subcategory & Return & Ranking \\
\hline Single business & 0,1431 & 5 \\
Dominant-Vertical & 0,0824 & 9 \\
Dominant-Constrained & 0,1659 & 2 \\
Dominant-Linked & 0,1424 & 6 \\
Dominant-Unrelated & 0,0994 & 8 \\
Related-Constrained & 0,1681 & 1 \\
Related-Linked & 0,1243 & 4 \\
Unrelated-Passive & 0,1374 & 7 \\
Conglomerate & 0,1611 & 3
\end{tabular}

*Andrews, G.S. Strategy and financial performance of South African industrial companies. Unpubl. Ph.D. Thesis, Graduate School of Business, University of Cape Town, 1979, p.377, Table 6-18.

Dominant-Vertical, in which the family companies performed better than the RDM 100 only $29 \%$ of the time, and worse $57 \%$ of the time. Andrews found that the Dominant-Vertical strategy had the lowest ROIC of all nine categories.

\section{Dominant-Unrelated companies}

The Dominant-Unrelated family companies, however, performed better than expected - they performed better than the RDM $10050 \%$ of the time, and worse only $31 \%$ of the time. A possible explanation for this is that the family companies which have chosen this strategy have considerably more talent in terms of core skills than they realise, and have chosen a small-scale UnrelatedDiversification strategy.

\section{Related-Constrained companies}

The Related-Constrained family companies performed exceptionally well, as was expected in the light of Andrews' study. As a group, these family companies performed better than the market $54 \%$ of the time, and worse $38 \%$ of the time. In Andrews' study, the RelatedConstrained strategy ranked as number one in terms of ROIC (16,8\%).

Companies which remain close to the core skills of the business seem to have considerable success in managing the transition from undiversified to diversified strategies. However, the number of companies which have made the transition successfully and remained in that category is noticeably small - only $12 \%$ of the family companies (which corresponds closely to the $12,9 \%$ of all industrial companies which Andrews classified as being in this category).

\section{Unrelated-Passive companies}

The Unrelated-Passive family companies have proved manifestly unsuccessful as a group, performing aboveaverage only $27 \%$ of the time, and worse $60 \%$ of the time in the period 1973-1977. The study by Andrews ranked this strategy seventh out of nine; this investigation ranks Unrelated-Passive as the worst of the possible categories.

\section{Conglomerate strategy}

The results of the Conglomerate business strategy can be misleading as only one company, the Anglo American Corporation, is represented. Nevertheless, the Conglomerate strategy results confirm Andrews' findings, that in South Africa the strategy is singularly successful. As conglomerates do not participate in the management of their acquisitions, the limitations normally experienced by family businesses - namely lack of sufficient talent and expertise - does not represent a major problem. The major problem becomes raising enough capital to pay for the acquisitions.

Those family companies which have taken a small step towards diversification $(27 \%)$ have generally not been successful either, particularly the dominant-linked and dominant vertical strategies. This supports the view that half-hearted attempts at diversification are generally unsuccessful.

In contrast, the strongly diversified strategies, Related and Unrelated, are the most successful. Very few family companies, however, make the transition or make it successfully, and the Unrelated-Passive companies are remarkably poor performers.

\section{Concluding observations}

It could be argued therefore that the family businesses, owing to lack of specialized functional skills (finance, marketing, production) lack of adequate succession in the family business line, and the reluctance of the founder to release the reins to others, generally do not have the skills to successfully integrate a growing, diverse and divisionalized business operation. Both the first and second hypotheses can therefore be accepted: familyowned listed companies are predominantly clustered in the Single Business strategy; and the more highly diversified companies have performances superior to those in the less diversified strategic categories.

\section{References}

1 SCOTT, B.R. Stages of corporate development, ICH 9: $371-294$, Case Clearing House, Harvard Business School: Boston, Mass., 1971.

2 WRIGLEY, L. Divisional autonomy and diversification. Unpubl. D.Ba. Dissertation, Harvard Business School: Boston, Mass., 1970.

3 ANDREWS, G.S. Strategy and financial performance of South African industrial companies. Unpubl. Ph.D. Thesis, Graduate School of Business, University of Cape Town, Rondebosch, RSA, 1979.

4 RUMELT, R.P. Strategy, structure, and economic performance. Harvard, University Press, Boston Mass., 1974.

5 MORGAN, I. IDB on the JSE. Mgmt, October 1979, pp. 63-78. 